\title{
Deriving Wealth from the Dry Matter of Some Under-Utilised Plant Parts
}

\author{
Otoide, J. E. ${ }^{* 1}$, Ihinmikaiye, S. O. ${ }^{2}$ And Otoide, T. F. ${ }^{3}$ \\ ${ }^{1}$ Department of Plant Science and Biotechnology, \\ Faculty of Science, Ekiti State University, Ado-Ekiti. \\ ${ }^{2}$ Department of Biological Sciences, Faculty of Science \\ Federal University, Otuoke, Bayelsa State. \\ ${ }^{3}$ Science Education Laboratory, Department of Science Education, \\ Faculty of Education, Ekiti State University, Ado-Ekiti.
}

\begin{abstract}
The possibility of creating wealth in pulp and paper industry from the underutilized dry matters of the leaf sheaths of the pseudostem (Musa paradisiaca and M. sapientum), leaf stalk (Carica papaya) and stems (Panicum maximum and Andropogon tectorum) have been established from the anatomical parameters and indexes (fibre lengths and diameters, lumen width, cell wall thickness, Runkel's ratio, flexibility coefficient (\%) and slenderness ratio) of the fibres using standard procedures. Results obtained revealed that the Runkel's ratio of the fibres in the five dry matters were $0.60,0.44,0.40,0.87$ and 0.93 for Musa sapientum, M. paradisiaca, Carica papaya, Panicum maximum and Andropogon tectorum respectively. These values, each been less than $1(<1)$ recommends each of the dry matters as suitable alternative source of raw materials for pulp and paper production industry. It was recommended that these dry plant materials be henceforth harnessed as alternative sources of raw materials for pulp and paper production industry as another means of wealth creation instead of allowing them to waste and cause environmental nuisance.
\end{abstract}

Key Words: Runkel's ratio, underutilized, wealth, dry matters, fibres, pulp and paper.

\section{Introduction}

Driven by increasing global environmental awareness and the increasing demand for paper, the past decades have witnessed lots of inquest into alternative resources that could serve as viable and sustainable alternatives to wood in the pulp and paper industry, resulting in major development of pulping technologies and processes that are considered to be environmentally benign (Fagbemigun et. al., 2016).

Paper Industry in Nigeria is currently bedeviled with myriad of problems. One of which include the unavailability of good forest woods and fibrous materials suitable for pulp and paper production. This has resulted in inadequate capacity utilization in the primary pulp and paper mill and massive loss of jobs and capital investment in the sector (Ogunwusi et. al. 2013). In order to get out of this conundrum, it has become expedient to intensify research study on materials, particularly, non-wood biomass that have been found to possess tremendous variations in chemical and physical properties compared to wood (Fagbemigun et. al. 2014).

According to FAO (2011) production of bananas has grown rapidly in Africa over the past 15 years, now accounting for around 4\% of the world banana trade. With an average consumption level of 190 $\mathrm{kg} /$ person/year, Nigeria produces more than 100 million tonnes of banana (sapientum) and plantain (Musa annually and ranked as one of the 20 most important banana and plantain producing countries worldwide. Plantain is widely used to describe the edible fruit that has more starch, thicker skin and typically larger than the common banana. Banana and plantains play an important role in the diet of people in Central and West 
Africa. They contribute significantly to food security and provide more than $10 \%$ of daily intake of carbohydrates and calories, respectively, for more than 70 million people in Sub-Saharan Africa (IITA, 2000). Most of the edible bananas are also cultivated mainly for their fruits, thus banana farms could generate several tons of underused by-products and wastes such as banana peel, banana stalk or peduncle, banana leaf These wastes, mostly dumped indiscriminately, constitute an environmental menace in developing countries like Nigeria due to non-availability of acceptable and safe solid disposal technique, as well as technology for their commercial utilization.

Banana waste, for instance, causes pests, and interfere with soil cultivation (Hussain and Tarar, 2014). It also produces toxic gases including $\mathrm{CO}$ give growth to harmful fungi which attacks remaining banana trees thereby creating an environmental imbalance. Agricultural is therefore one of the most important problems that must be resolved for the conservation of global environment. Growing usefulness of agro-wastes in wide variety of applications has been reported. About $11 \%$ of world pulp production is made from nonwood fibrous raw materials, some of which are agricultural raw materials. The raw material used by the pulp industries in China and India comes from non woody plants which are mostly agricultural residues that consists mostly of straw and bagasse. Rice husk, jute, stalk, baggase, groundnut shell and coconut fiber, etc. are also produced in large quantities. Pineapple leaf has been found to possess tremendous mechanical properties which make it suitable for the production of reinforced polymer composites. There has also been wide utilization of whole banana plant in food, feed, pharmaceutical, packaging and many industrial applications such as waste water treatment, biogas, wine/ethanol production, food wrapping etc. Pineapple and banana wastes are very good source of cellulose and therefore represent potential natural fibres sources for the pulp and paper industry. Pineapple leaves in Malaysia is composed of over $60 \%$ Cellulose and $85 \%$ holocellulose, which is higher than that obtained for most wood fiber. The condensed arrangement of fibre is also an important factor in pulp and paper production from pineapple leaves. Biodegradability, flexibility, availability, easy pulping capability, sustainability, low cost of processing and acquisition are few of the factors that make these materials veritable resources (Fagbemigun et al. 2016).

Plantain (Musa paradisiaca) is a member of Musaceac family. The plant is one of the earliest cultivated crops, originating from the South East Asia. Today they are found in many countries that have the tropical rainforest types of climate; they are found in West Africa, India, Jamaica, the Cameroon and some other African countries. The fruits are eaten when unripe and in ripe form and are very important in the international trade. In Nigeria, plantain which are grown together with banana (Musa sapientum) are found mostly in the Southern States namely; Edo, Oyo, Ondo, Cross River, Akwa Ibom, Abia, Imo, Rivers, Bayelsa and Delta States, where the fruits form the stable food for the people as well as an important article of trade with the northern states and other West African Countries. The plant grows for about six to seven months to reach maturity for fruiting, after which the aerial stem is felled, the fruit cut off and the stem is allowed to rot away. This is because the plant is propagated by the sucker, an underground stem which produces new shoots. Both the plantain and the banana pseudostems are fleshy and soft, they are actually the lower parts of the leaves folded together and structures with some intercellular openings are found within each fold; there is a large fleshy central core at the centre of the folds. The folds can easily be separated by hand. The core transports the nutrients from the roots to the upper part of the plant and finally terminates in fruit formation. The green pseudostem contains much water that fills up the intercellular openings. The pseudostem except the core is made up of cellulosic filaments which are bonded together into cellulosic films by lignin and hemicelluloses. Through pulping process the fibres that make up the filaments are separated. Locally the filaments can be made into strands for making ropes and textile materials such as clothing (Akpabio and Akpakpan, 2012)

Carica papaya L. is an evergreen, tree-like herb, 2-10 m tall, usually unbranched, although sometimes branched due to injury, containing white latex in all parts. Stem cylindrical, $10-30 \mathrm{~cm}$ in diameter, hollow with prominent leaf scars and spongy-fibrous tissue. Has an extensive rooting system. Leaves spirally arranged, clustered near apex of trunk; petiole up to $1 \mathrm{~m}$ long, hollow, greenish or purplish-green; lamina orbicular, $25-75 \mathrm{~cm}$ in diameter, palmate, deeply 7-lobed, glabrous, prominently veined; lobes deeply and broadly toothed. Flowers tiny, yellow, funnel-shaped, solitary or clustered in the leaf axils, of 3 types; female flowers 3-5 cm long, large functional pistil, no stamens, ovoid-shaped ovary; male flowers on long hanging panicles, with 10 stamens in 2 rows, gynoecium absent except for a pistillode; hermaphrodite 
flowers larger than males, 5-carpellate ovary; occurrence depends on the season or age of the tree. Fruits large, cylindrical, with fleshy orange pulp, hollow berry, thin yellowish skin when ripe, varied. Fruits formed from female flowers are oblong, spherical, pear-shaped; from hermaphrodite flowers, long, obovoid or pyriform. Seeds numerous, small, black, round, covered with gelatinous aril. Small latex vessels extend throughout the tree and are particularly abundant in fruit that has reached full size but has not yet begun to ripen (Orwa et al. 2009).

Panicum maximum Jacq is a perennial, tufted grass with a short, creeping rhizome. The stems of this robust grass can reach a height of up to $2 \mathrm{~m}$. As the stems bend and nodes touch the ground, roots and new plants are formed. The leaf sheaths are found at the bases of the stems and are covered in fine hairs. It remains green until late into winter. The leaf blades are up to $35 \mathrm{~mm}$ wide and taper to a long fine point. The inflorescence is a large multi-branched, open panicle with loose, flexuous branches. The lower branches of the inflorescence are arranged in a whorl. The lower floret is usually male with a well-developed palea (upper bract enclosing flower). The fertile (female) upper lemma is pale. Spikelets are green to purple and flowering occurs from November to July. This species varies in size and hairiness and may also vary to a lesser extent in growth habit. There are distinct forms of Panicum in South Africa, but the transversely wrinkled upper floret or seed of P. maximum, distinguishes it from all other Panicum species (Gibbs et al, 1991).

Andropogon tectorum Schumach. \& Thonn. [Poaceae] is a robust perennial grass with culms to $3 \mathrm{~m}$ high, often stilt-rooted; of shady sites under trees; common across the Region from Senegal to W Cameroons, and on into Central African Republic. This grass has close affinity to A. gayanus, but with distribution rather to the southward where it is an important pasture grass. It is readily grazed before anthesis by all stock. It is deemed especially good fodder for horses. The culms are commonly cut in Sierra Leone for use in fencing. They are stout and pithy, and are used for matting and for roofing. The culms are a common item of merchandise in Bamako markets in Mali sold for matting, screens and roofing. In Ubangi, a root-decoction is given to women for stomach-ache. The grass may have some potential as a source of honey: bees in Abeokuta Province of S Nigeria have been observed collecting pollen. Tenda in SE Senegal have ritual use of the grass during funerals (Burkill, 1985).

In the recent time, researchers have become more inquisitive about the anatomy, morphology and physical properties of fibres in plants vis-avis the possible end use(s). Notable among these are Razak et al. (2010), Aina et al. (2012), Otoide (2013), Sharma et. al. (2013), Otoide (2014), Otoide (2015), Otoide (2016), Sadiku et al (2016), Otoide (2017), Otoide et. al. (2018 a \& b) and Otoide and Omotayo (2019). Razak et al. (2010) reported increment in thickness of fibre and parenchyma cell walls from 2 to 4 year-old culms of Bambusa vulgaris. Also, Aina et al. (2012) reported the possible usage of culms of Bambusa vulgaris for the production of paper and as building and structural materials due to the characteristics of the fibres. Similarly, Otoide (2013) reported the presence of libriform, non-septate and medium sized fibres in the stem of a fully grown species of Adansonia digitata. Furthermore, Sharma et. al., (2013) evaluated the characteristics of fibres in some weeds of Arunachal Padesh, India for pulp and paper making. More so, Otoide (2014) studied the fibres in the stem of Afzelia africana by measuring their lengths and diameters in micrometer and recommended the usage of the species for construction works and any other production in which woods with extremely short fibres will not negatively affect the end product of production. Still, Otoide (2015) reported the presence of very short fibres and Runkel's ratio of less than one in the trunk of Citrus sinensis and recommended it as alternative source of raw materials for pulp and paper industries. In the same vein, Otoide (2016) carried out the morphometric analysis of the fibres in the trunk of Alstonia boonei and reported occurrence of medium sized, thick-walled and aseptate libriform fibres with living protoplasm and thereafter, recommended the species for construction of shelterbelts for inhabitants of areas disturbed by wind and windstorm as well as construction of yam and animal barns for subsistent and commercial agriculture. Furthermore, Sadiku et. al., (2016) studied the dimension and chemical characterization of the fibres in culm of naturally grown Bambusa vulgaris and recommended the production of pulp and paper from the culm because of the Runkel's ratio which was below one. Similarly, Otoide (2017) reported the presence of highly thickened cell-walled fibres, libriform and aseptate fibres in the woody stem of Theobroma cacao. Similarly, Otoide et al,. (2018a) reported the occurrence of elastic fibres having felting power of more than 33 when mature stem of Tithonia diversifolia was studied to ascertain its potential use 
for pulp and paper making. They recommended the suitability of the stem for pulp and paper production. Still, Otoide et al., (2018b) assessed the anatomy of fibres in the trunk of Alstonia boonei for some derived indexes and recommended the species as alternative source of raw materials for pulp and paper making. Lastly on this narratives is the recent reports by Otoide and Omotayo (2019) on Bambusa vulgaris. They recommended the consideration of stem of Bambusa vulgaris as alternative source of raw materials for pulp and paper production after analyzing the flexibility coefficient and slenderness ratio of the fibres.

The present study is undertaken in order to deduce and ascertain the possibility of creating wealth from these underutilized plant parts in pulp and paper making industry.

\section{Materials and Methods}

Collection of Samples: Dried leaf stalk (Carica papaya), stems (Panicum maximum and Andropogon tectorum) and the dried leaf sheaths of the Pseudo-stem of Musa paradisiaca amd Musa sapientum were collected from cultivated farm land and bush fallows within Ekiti State University community around February and March, 2019. The plant parts were authenticated at the Herbarium of Ekiti State University, Ado-Ekiti.

Maceration and measurement of the fibres: This was carried out following (San et. al., 2016).

A small piece from the side of samples were cut and prepared for macerations. Maceration solution consisted of 30\% hydrogen peroxide and glacial acetic acid in a 1:1 ratio. The prepared reagent was applied to wood samples (fragmented to the size of the matches) in the glass tubes, after which the tubes were corked. The material in test tubes was transformed into pulp in the oven at a temperature of $65^{\circ} \mathrm{C}$ for the period of $24 \mathrm{~h}$. After rinsing with distilled water and shaking individual cells of xylem tissue suitable for measuring were obtained. Macerated wood fragments are transported to the glass slide with a dissecting needle and they are observed under microscope. Fiber length, thickness of cell walls and lumen diameters were measured using the system consisting of Leica DMLS microscope and a camera: Leica DC 300 supported by Leica IM 1000 software which enabled digital recording of prepared preparations and very precise electronic measurement of the mentioned anatomical elements. A total of 800 fibers were measured from each of the plant materials to achieve the accuracy of properties evaluated.

\section{Determination of the derived indexes}

From the data, the average fiber dimensions were calculated and then the following derived indexes were determined:

$$
\text { Runkel's ratio }=\underline{2 \times \text { Wall thickness }}
$$

$$
\text { Lumen Width }
$$

$$
\text { Flexibility coefficient }(\%)=\frac{\text { Lumen Width of Fiber }}{\text { Diameter of Fiber }} \times \frac{100}{1}
$$

\section{Slenderness ratio $=\underline{\text { Length of Fiber }}$}

Diameter of Fiber

\section{Results and Discussion}

The anatomical parameters and the derived indexes of the fibres in the plant parts have been summarized in Table 1.

The fibres in the dry leaf sheaths of the Pseudo-stems of Musa sapientum and Musa paradisiaca gave lengths of $1.74 \pm 0.39$ and $1.97 \pm 0.54$ respectively, while their diameters were $17.17 \pm 0.39$ and $19.61 \pm 5.65$ respectively. Similarly, The lengths and diameters of the fibres extracted from the dry leaf petiole of Carica papaya were $2.62 \pm 0.74$ and $19.45 \pm 5.00$. On the other hand, the fibres in the dry stems of Panicum 
maximum and Andropogon tectorum gave lengths of $1.46 \pm 0.47$ and $1.48 \pm 0.38$ while the diameters were $21.02 \pm 7.10$ and $20.09 \pm 9.59$ respectively.

The lumen widths of the fibres in Musa sapientum, M. paradisiaca, Carica papaya, Panicum maximum and Andropogon tectorum were $9.28 \pm 2.77,11.06 \pm 4.24,10.56 \pm 2.99,11.80 \pm \quad 5.57$ and $10.99 \pm 6.38$ respectively while their cell wall thicknesses were $3.95 \pm 0.98,4.28 \pm 1.10,4.44 \pm 1.41,4.60 \pm 1.73$ and $4.55 \pm 1.85$ respectively.

Runkel's ratio values of $0.60,0.44,0.40,0.87$ and 0.93 were derived for fibres in $M$. sapientum, $M$. paradisiaca, Carica papaya, Panicum maximum and Andropogom tectorum respectively, while the Flexibility Coefficient (\%) of the fibres in them were 40.00, 40.00, 36.84, 54.87 and 52.79 respectively.

The fibres in the plant parts gave Felting Powers of $106.70 \pm 32.07,108.86 \pm 40.98,144.68 \pm 56.52,83.32 \pm$ 53.85 and $92.36 \pm 52.66$ for Musa sapientum, M. paradisiaca, Carica papaya, Panicum maximum and Andropogon tectorum respectively.

According to the groupings of fibres by Metcalfe and Chalke (1989), it suffices to infer that the fibres in all the samples in the present investigations fall within the range of short fibres. Wood fibres are usually cellulosic elements that are extracted from trees and used in the manufacture of pulp and paper or fibre board. Otoide et al (2018) asserted that the morphological characteristics of fibres are important because it determines the suitability of the lignocellulosic material before proceeding to paper production.

Derived anatomical indexes such as Runkel's ratio, Flexibility Coefficient (\%) and Slenderness ratio are indispensable parameters in the selection of fibres suitable for pulp and paper production (San et al, 2016, Egbewole et al, 2015 and Otoide et al., 2018). Consequently, the Runkel's ratio of the fibres in all the plant parts investigated were less than $1(<1)$. This value recommends them as suitable raw materials for the production of pulp and paper. This assertion is in line with the previous recommendations of Jang and Seth (1998) and San et al (2016) that fibres with low Runkel's ratio $(<1)$ will produce good quality pulp and paper and that paper will show poor bonding ability and low flexibility when the Runkel's ratio is greater than $1(>1)$.

The Flexibility Coefficient of the fibres in Musa sapientum, M. paradisiaca and Carica papaya were between 30-50 whereas, those of Panicum maximum and Andropogon tectorum were between 50-75. Based on these, M. sapientum, M. paradisiaca and Carica papaya fall within the class of rigid fibres while Panicum maximum and Andropogon tectorum fall within the class of elastic fibres according to the previous reports of Samariha et al (2011). Flexibility Coefficient gives the bonding strength of individual fibre and by extension the tensil strength and bursting propertis (San et al., 2016).

The slenderness ratio of felting power of the plant parts in the present study were more than 33 . Therefore, it suffices to assert that the dry leaf sheaths of the pseudostems of M. sapientum and M. paradisiaca including the dry long petiole of Carica papaya will produce better forming and well bonded paper when used as raw materials in pulp and paper production. This is also applicable to the dry stems of Panicum maximum and Andropogon tectorum in which the slenderness ratio were more than 33.

Conclusively, in Nigeria, Musa sapientum, M. paradisiaca and Carica papaya are often cultivated for human consumption. Though sometime they grow naturally in the wild. Notwithstanding, their body parts which have been extracted for the present study are normally considered as wastes and there underutilized. Similarly, Panicum maximum and Andropogon tectorum are never cultivated in Nigeria. They only grow naturally in the wild though, they serve as forages for grazing animals when fresh. The dry ones however, are usually considered as wastes. In the light of the foregoing, it is worthwhile to suggest that the dry leaf sheaths of Musa sapientum and M. paradisiaca, the dry hollow petiole of Carica papaya, the dry stems of Panicum maximum and Andropogon tectorum be, from now onward, harnessed as alternative sources of raw 
materials for pulp and paper production instead of allowing them to waste and constitute environmental nuisance. This done, will be additional means of wealth creation.

Table 1: Anatomical Characteristics Of The Fibres In The Under-Utilized Plant Parts

\begin{tabular}{|c|c|c|c|c|c|}
\hline \multirow[b]{2}{*}{ Properties } & \multicolumn{5}{|c|}{ Plant Parts } \\
\hline & A & B & C & D & $\mathrm{E}$ \\
\hline $\begin{array}{l}\text { Fibre length } \\
(\mathrm{mm})\end{array}$ & $1.74 \pm 0.39$ & $1.97 \pm 0.54$ & $2.62 \pm 0.74$ & $1.46 \pm 0.47$ & $1.48 \pm 0.38$ \\
\hline $\begin{array}{l}\text { Fibre diameter } \\
(\mu \mathrm{m})\end{array}$ & $17.17 \pm 0.39$ & $19.61 \pm 5.65$ & $19.45 \pm 5.00$ & $21.02 \pm 7.10$ & $20.09 \pm 9.59$ \\
\hline $\begin{array}{l}\text { Lumen width } \\
(\mu \mathrm{m})\end{array}$ & $9.28 \pm 2.77$ & $11.06 \pm 4.24$ & $10.56 \pm 2.99$ & $11.80 \pm 5.57$ & $10.99 \pm 6.38$ \\
\hline $\begin{array}{l}\text { Cell wall } \\
\text { thickness }(\mu \mathrm{m})\end{array}$ & $3.95 \pm 0.98$ & $4.28 \pm 1.10$ & $4.44 \pm 1.41$ & $4.60 \pm 1.73$ & $4.55 \pm 1.85$ \\
\hline Runkel's ratio & 0.60 & 0.44 & 0.40 & 0.87 & 0.93 \\
\hline $\begin{array}{l}\text { Flexibility } \\
\text { coefficient (\%) }\end{array}$ & 40.00 & 40.00 & 36.84 & 54.87 & 52.79 \\
\hline $\begin{array}{l}\text { Slenderness } \\
\text { ratio/Felting } \\
\text { power }\end{array}$ & $106.70 \pm 32.07$ & $108.86 \pm 40.98$ & $144.68 \pm 56.52$ & $83.32 \pm 53.85$ & $92.36 \pm 52.66$ \\
\hline
\end{tabular}

KEY: $\mathrm{A}=$ Musa sapientum, $\mathrm{B}=$ Musa paradisiaca, $\mathrm{C}=$ Carica papaya, $\mathrm{D}=$ Panicum maximum, $\mathrm{E}=$ Andropogon tectorum

\section{References}

[1] Aina, K. S., Areghan, S. E., Adeniyi, I. M., Alao, O. J. and Osuntuyi, E. O. (2012). Variability studies on strength and fibre properties of Bambusa vulgaris Schrad. for panel products. PROLIGNO. 8 (1): 3-14.

[2] Akpabio, U. D; Akpakpan, A. E. (2012). Pulp and paper from agricultural wastes: Plantain pseudostem waste and crew pine leaves. International Journal Chemical Modelling. 2(3):100-107.

[3] Burkill, H. M. (1985). The Useful Plants of West Tropical Africa, Vol. 1, AD Royal Botanic Gardens Kew. The Whitefriars Press Ltd., London.

[4] Egbewole, Z. T., Rotowa, O. J. and Omoake, P. O. (2015). Evaluation of Fibre Quality of Bambusa vulgaris (Bamboo) as a Raw Material for Pulp and Paper Production. PAT. 11(2): 188-202.

[5] Fagbemigun, T. K; Fagbemi, O. D; Otitoju, O; Mgbachiuzor, E; Igwe, C. C. (2014): Pulp and papermaking potential of corn husk. International Journal of AgriScience. 4 (4):209-213.

[6] Food and Agriculture Organisation (FAO)(2011). Production, commodity by country. FAOSTAT Data;. Available:http://faostat.fao.org/sit e/339/default.aspx

[7] International Institute of Tropical Agriculture (IITA) (2000). Improving plantain and Banana based. IITA Project 2, Annual Report, Ibadan. 67.

[8] Fagbemigun, T. K., Fagbemi O. D, Buhari, F., Mbgbachiuzo, E., Igwe C. C. (2016): Fibre Characteristics and Strenght Properties of Nigerian Pineapple Leaf (Ananas comosus), Banana Penduncle and Banana Leaf (Musa sapientum)-Potential Green Resources for Pulp and Paper Production. Journal of Scientific Research and Reports. 12(2): 1-13

[9] Gibbs, R. G. E.; Watson, L.; Koekemoer, M.; Smook, L.; Barker, N. P.; Anderson, H. M. and Dallwitz, M. J. (1990). Grasses of Southern Africa. Memoirs of the Botanical Survey of South Africa. No. 58: 10-11. 
[10] Hussain, I.; Tarar, O. M. (2014). Pulp and paper making by using waste banana stem. Journal of Modern Science and Technology. 2(2):36-40.

[11] Jang, H. F and Seth, R. S. (1998). Using confocal microscopy to characterize the collapse a. behavior of fibers. Tappi J. 81: 167-174.

[12] Ogunwusi, A. A.; Onwualu, A. P.; Ogunsanwo, O. Y. (2013): Comparative analysis of wood properties of Afzelia africana and Anogeissus leiocarpus growing in Nigeria. Chemistry and Materials Research.3 (3):

[13] Otoide, J. E. (2013). Wood density and fibre composition of the stem of Adansonia digitata Linn. Bulletin of Pure and Applied Sciences. Vol.32B - Botany. 1: 21-27.

[14] Otoide, J. E. (2014). Study of fibres in stem of Afzelia africana Sm. ex pers. Ind. J. Sci. Res. and Tech. 2(1): 102-107.

[15] Otoide, J. E. (2015). Fibre characteristics of the trunk of Citrus sinensis (L.) Osbeck. IOSR Journal of Pharmacy and Biological Sciences (IOSR-JPBS). 10(6): 76-81.

[16] Otoide, J. E. (2016). Morphometric Analysis of the Fibres in the Trunk of Alstonia boonei. Journal of Natural Sciences Research. 6(24): 9-14.

[17] Otoide, J. E. (2017). Evaluations of vessel elements and rays in the trunk of Theobroma cacao. Bulletin of Pure and Applied Sciences. 36B (1) (Botany): 1-9

[18] Otoide, J. E. and Omotayo, F. O. (2019). Microstructural Examination of Culm Fibres of Bambusa vulgaris Schrad. ex. J. C. Wendl. America Research Journal of Biosciences. 5 (11): 1-5

[19] Otoide, J. E., Jayeola, A. A. and Akanni, B. A. (2018a). Pulping and Paper Making Potentials of Stem of Tithonia diversifolia. European Journal of Botany, Plant Science and Physiology. 4(1): 1-5

[20] Otoide, J. E., Tedela, P. O., Akerele, O. D. and Adetunji, D. O. (2018b). Anatomical assessment of the fibers in the trunk of Alstonia boonei for some derived indexes. World News of Natural Sciences. 20: $54-61$

[21] Orwa, C.; Mutua, A.; Kindt, R.; Jamnadass, R.; Anthony, S. (2009). Agroforestree Database:a tree reference and selection guide version 4.0 (http://www.worldagroforestry.org/sites/treedbs/treedatabases.asp)

[22] Razak, W.; Mohd, T. M.; Othman, S.; Aminuddin, M.; Affendy, H. and Izyan, K. (2010). Anatomical and Physical Properties of Cultivated Two- and Four-year-old Bambusa vulgaris. Sains Malaysiana.39 (4): 571-579

[23] Sadiku, N. A.; Oluyege, A. O. and Ajayi, B. (2016). Fibre dimension and chemical characterization of naturally grown Bambusa vulgaris for pulp and paper production. J. Bamboo and Rattan. 15(1-4): 33-43.

[24] San, H. P.;Long, L. K.; Zhang, C. Z.; Hui, T. C.; Seng, W. Y.; Lin, F. S.; Hun, A. T. and Fong, W. K. (2016). Anatomical Features, Fiber Morphological, Physical and Mechanical Properties of Three Years Old New Hybrid Paulownia: Green Paulownia. Research Journal of Forestry. 10: 30-35.

[25] Sharma, M.; Sharma, C. L. and Kumar, Y. B. (2013). Evaluation of Fiber Characteristics in some weeds of Arunachal Pradesh, India for Pulp and Paper Making. Research Journal of Agriculture and Forestry Sciences. 1(3): 15-21. 